\title{
EFFECT OF SOME PRE AND POST-HARVEST TREATMENTS ON THE KEEPING QUALITY OF POINSETTIA CUT-FLOWERS: \\ II. VASE LIFE AS AFFECTED BY AGRICULTURAL PARACTICES AND HOLD SOLUTIONS. \\ Hussein, H.A.A.; A.M. Hamza and Maha M. M. Fayed \\ Veget. and Floric. Dept., Fac. of Agric., Mansoura Univ.
}

\begin{abstract}
A comprehensive postharvest study on poinsettia cut flowers was carried out during the two successive seasons of 1997/98 and 1998/99 at the Veget. and Flor. Dept., Faculty of Agriculture, Mansoura University to evaluate the effect of a Super Grow fertilizer at $0.0,0.3,0.6$ and $0.9 \mathrm{~g} /$ plant once weekly combined with different irrigation levels of 150,300, 450 and $600 \mathrm{ml} /$ plant once every 3 days and different flower holding solutions as follows : sucrose $(15 \mathrm{~g} / \mathrm{L})$, silver nitrate $(25 \mathrm{ppm})$, boric acid (10 ppm), citric acid (10 ppm) and their interaction on vase life and quality of cut poinsettia flowers.

The obtained results indicated that the heaviest flowers weight $(19.87 \%)$ resulted from treated plants with the fertilizer at $0.9 \mathrm{~g} / \mathrm{plant}$, irrigated with $450 \mathrm{ml} / \mathrm{plant}$ combined with holding flowers in citric acid $(10 \mathrm{ppm})+$ sucrose $(15 \mathrm{~g} / \mathrm{L})$ solution. Moreover, the highest water uptake $(3.26 \mathrm{ml} / \mathrm{fl})$, the best positive water balance $(0.94$ $\mathrm{ml} / \mathrm{fl} . / \mathrm{day}$ ) and the longest vase life (19.75 days) were produced from plants treated with the fertilizer at $0.9 \mathrm{~g} / \mathrm{plant}$, irrigated with $450 \mathrm{ml} / \mathrm{plant}$ and combined with holding flowers in silver nitrate $(25 \mathrm{ppm})$. However, the fertilized plants with $0.3 \mathrm{~g} / \mathrm{plant}$ and irrigated with the minimum water level of $150 \mathrm{ml} /$ plant showed almost half the vase life prementioned ( 9.0 day) when hold in water only in the first season.

The present study recommended that applying Super Grow fertilizer at 0.9 $\mathrm{g} / \mathrm{L}$ once every week, with irrigation level at $450 \mathrm{ml} /$ plant once per 3 days and combined with holding flowers in silver nitrate $(25 \mathrm{ppm})$ to obtain the longest vase life and best quality of poinsettia cut flowers.
\end{abstract}

\section{INTRODUCTION}

The cut flowers of poinsettia (Euphorbia pulcherrima, Willd) Fam. Euphorbiaceae represent one of the most popular flowering pot plants in the world, particularly in the United States, Canada and European countries when they produce it for the Christmas season (James, 1980).

Short vase life of flowers could be one of the most important reasons for the inability of florists to develop any appreciable market. The cut inflorescences of poinsettia tend to have a very short vase life which reduces their potential as a commercial cut-flower. Poinsettia plant contains laticifers which are series of fused cells containing a milky sap called latex and forming systems that permeate various tissues of the plant body. Once poinsettia flowers are cut from the plant, latex fuses out of the inflorescences stem, plugging the conducting vessels at the cut base of the inflorescences stem and prevents water uptake causing a rapid wilting of the inflorescences. Through the years, many methods to condition cut flowers, which exude latex, have been investigated, these methods included searing of the base 
Hussein, H. A. A. et al.

over a flame or steam, dippin the stem in a boiling water and pulsing in alcohol (Halevy and Mayak, 1981 and Gordon et al., 1986).

The main objective of this work was to overcome the relatively short vase life, growth of micro-organisms and/or to antagonize ethylene by (silver nitrate) and other different components of the flower holding solution such as sucrose alone (as a source of carbohydrates), sucrose plus boric acid and sucrose plus citric acid.

Herein experiment, the effects of interactions only between fertilization, irrigation and holding solutions treatments on maximum increase of flower fresh weight, water relations and vase life of poinsettia cut-flowers were evaluated.

\section{MATERIALS AND METHODS}

The present investigation was carried out during 1997/98 and 1998/99 seasons at the Experimental Station, Faculty of Agriculture, Mansoura University, Egypt. During growing period plants were treated with a Super Grow fertilizer at 0.0, 0.3, 0.6 and $0.9 \mathrm{~g} /$ plant once weekly. Irrigation levels were 150, 300, 450, $600 \mathrm{ml} /$ plant every 3 day, weekly.

The flowers were cut when their bracts were fully colored and pollen has been shed from the cyathium, early in the morning and moved to the floriculture laboratory, stem length was trimmed to $30 \mathrm{~cm}$ at harvesting time. Leaves were removed from the lower part of stem leaving only the uppermost three leaves. The lower two $\mathrm{cms}$ of flowers stem were placed in alcohol (95 $\%$ ethanol) for 10 minutes, according to Freyermuth et al. (1984) to stop latix, then weighed and placed individually in $100 \mathrm{ml}$ graduated cylinder glass filled with different designated holding solutions and left in the laboratory conditions at $23 \pm 2{ }^{\circ} \mathrm{C}$ and $60 \pm 5 \%$ relative humidity.

The flowers were placed in the holding solutions until the end of the experiment as follows :

1- Distilled water (DW). 2- Sucrose solution (15 g /liter).

3- Silver nitrate solution ( $\left.25 \mathrm{ppm} \mathrm{AgNO}_{3}\right)$.

4- Sucrose solution (15 g /liter) + boric acid solution (10 ppm).

5- Sucrose solution ( $15 \mathrm{~g} /$ /iter $)+$ citric acid solution (10 ppm).

Each holding solution was replicated 10 times, additional ten graduated cylinders glasses filled water only were placed in the laboratory under the same conditions, in order to measure the common average daily evaporation value. All solutions were made up of distilled water.

The following data were recorded:

1- Flower fresh weight : the initial fresh weight was measured immediately after cutting the flower. Every $24 \mathrm{hrs}$, each flower was weighed in order to estimate the maximum fresh weight gain (\%) based on the initial fresh weight.

2- Water uptake (ml/flower) : daily water uptake was recorded as the daily decrease in the solution level of the greaduated cylinder glass. 
3- Water loss (ml/flower): daily water losses for each flower were calculated as the difference between daily change in fresh weight and amount of daily water absorption of the flower.

4- Water balance ( $\mathrm{ml} /$ flower/day): daily water balance was measured as the difference between water uptake and water loss of each flower.

5- Vase life (days) : the useful vase life of each flower was terminated when the flower lost $10 \%$ of its maximum fresh weight, the ray florets wilted or when shattering of the corolla and or petal scorch (browning of the petal edge) occurred.

A split-split plot design with 4 replicates per treatment was adopted. Each replicate contained 10 individual flowers. The main plot was the treatments of fertilization, and the sub-plot was the irrigation treatments, while the sub-sub plot was the holding solution treatments. Treatment differences were determined by analysis of variance procedure as mentioned by Gomez and Gomez (1984). Treatment means were compared using the least significant difference test (LSD), (probability $5 \%$ ).

\section{RESULTS AND DISCUSSION}

Data in Table (1) clarify the great variation in the values of fresh weight increase as affected by the interaction between the three factors. In a general view it was observed that the different values were in an assending order as the fertilization doses were increased. In addition, the values had an increase trend as irrigation levels were increased up to $450 \mathrm{ml} /$ plant following a dessending order, this reduction may be related to root damage related to bad aeration. These results were in agreement with the results obtained by Roy (1980) who mentioned that poinsettia requires high levels of the major elements particularly nitrogen soil fertility levels must be carefully controlled. However, the basic requirement of high nitrogen with moderate phosphorus and potassium can be met by complete fertilizers. In addition Nell et al. (1995) found that poinsettia longevity and quality are influenced by production and post-production factors.

Concerning the effect of the holding solutions it may be noted that citric acid (10 ppm) plus sucrose $(15 \mathrm{~g} / \mathrm{L})$ in general had a superior response in this respect. Simultaniously regarding the prementtioned observations it was obvious that the highest statistically significant value $(19.87 \%)$ resulted from plants which received $0.9 \mathrm{~g} /$ plant of fertilizer, irrigated with $450 \mathrm{ml} /$ plant at the growing period and treating its flowers with citric acid (10 ppm) plus sucrose $(15 \mathrm{~g} / \mathrm{L})$ when compared with the majority of the other values in the first season. Adding sugar alone to water in a flower vase, however, usually dose more harmful, since it results in a luxuriant growth of micro-organisms which cause problems. Thus, preservatives must contain an acid to reduce the $\mathrm{pH}$. This clarifies the importance of citric acid addition in this respect.

It may be noticed that the other values exposed to a similar preharvest treatments and hold in other preservatives were in most cases so close to the above mentioned value (19.87\%) except for those hold in water only. In this respect, the lowest value (10.02\%) was of non fertilized plants, irrigated with $150 \mathrm{ml} / \mathrm{plant}$ and hold in water only in the first season. The 
Hussein, H. A. A. et al.

values in the second season followed a similar trend when compared with the first season. The increment in flower weight means turgidity of the flower actually leading to a longer vase life.

Table (1) : Effect of the interaction between different fertilization, irrigation levels during plant growth period and holding solution treatments on maximum increase in fresh weight (\%) of poinsettia cut flowers during 1997/98 and 1998/99 seasons.

\begin{tabular}{|c|c|c|c|c|c|c|c|c|c|c|c|}
\hline \multirow{2}{*}{\multicolumn{2}{|c|}{ Treatments }} & \multicolumn{10}{|c|}{ Maximum increase in fresh weight \% } \\
\hline & & \multicolumn{5}{|c|}{ First season 1997/98 } & \multicolumn{5}{|c|}{ Second season 1998/99 } \\
\hline 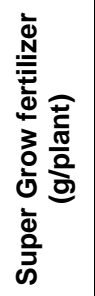 & 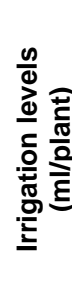 & 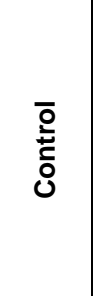 & $\begin{array}{l}\circ 0 \\
\text { in } \\
0 \\
\Phi \\
0 \\
0 \\
0 \\
\omega\end{array}$ & 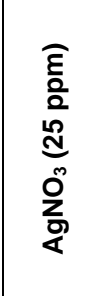 & 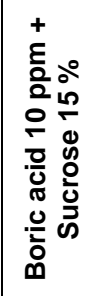 & $\begin{array}{l}+ \\
\stackrel{+}{E} \\
\frac{0}{2} \\
0\end{array}$ & 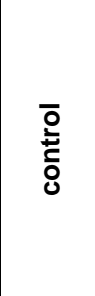 & 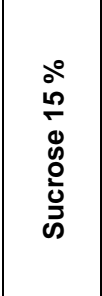 & 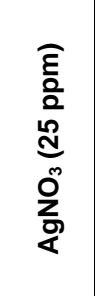 & 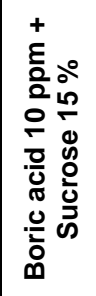 & 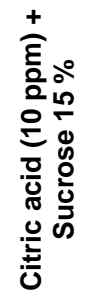 \\
\hline \multirow{4}{*}{ 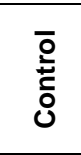 } & 150 & 2 & 11.73 & 0.00 & & 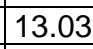 & 13.19 & & & 6.02 & 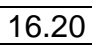 \\
\hline & 300 & 11.17 & 11.84 & 13.63 & 13.14 & 13.94 & 14.34 & 15.01 & 16.80 & 16.31 & 17.11 \\
\hline & 450 & 11.64 & 12.48 & 13.87 & 13.67 & 14.00 & 14.81 & 15.66 & 17.04 & 16.85 & 17.17 \\
\hline & 600 & 11.51 & 12.63 & 13.80 & 13.50 & 13.87 & 14.78 & 15.80 & 16.97 & 16.67 & 17.12 \\
\hline \multirow{4}{*}{$\stackrel{m}{a}$} & 150 & 14.07 & 14.19 & 14.78 & 14.62 & 15. & 17.31 & 17.31 & 18.11 & 17.90 & 18.69 \\
\hline & 300 & 14.91 & 14.98 & 14.83 & 14.70 & 15.62 & 18.16 & \begin{tabular}{|l|}
18.21 \\
\end{tabular} & \begin{tabular}{|l|}
18.21 \\
\end{tabular} & 18.14 & 18.86 \\
\hline & 450 & 15.08 & 15.17 & 15.75 & 15.60 & 16.39 & 18.32 & 18.47 & 18.99 & 18.84 & 19.43 \\
\hline & 600 & 15.00 & 15.11 & 15.62 & 14.27 & 15.97 & 18.24 & 18.35 & 18.06 & 18.31 & 18.31 \\
\hline \multirow{4}{*}{ c } & 150 & 15.63 & 15.80 & 16.09 & 15.92 & 16.64 & 18.89 & \begin{tabular}{|l|}
19.04 \\
\end{tabular} & 19.31 & 19.16 & 19.88 \\
\hline & 300 & 15.93 & 16.07 & 16.23 & 16.12 & 16.87 & 19.19 & 19.31 & 19.47 & 19.36 & 20.13 \\
\hline & 450 & 16.72 & 16.43 & \begin{tabular}{|l|}
16.87 \\
\end{tabular} & 16.45 & 17.05 & \begin{tabular}{|l|}
19.96 \\
\end{tabular} & \begin{tabular}{|l|}
19.67 \\
\end{tabular} & 20.14 & \begin{tabular}{|l|}
19.69 \\
\end{tabular} & 20.29 \\
\hline & 600 & 16.00 & 16.09 & 16.54 & 16.19 & 16.94 & 19.26 & 19.33 & 19.98 & 19.43 & 20.18 \\
\hline \multirow{4}{*}{$\stackrel{9}{0}$} & 150 & 17.00 & 18.33 & 18.94 & 18.42 & 19.03 & 20.30 & 21.63 & 22.14 & 21.72 & 22.33 \\
\hline & 300 & 17.34 & 18.93 & 19.21 & 19.00 & 19.53 & 20.64 & 22.18 & 22.51 & 22.30 & 22.88 \\
\hline & 450 & 17.89 & 19.11 & 19.62 & 19.31 & 19.87 & 21.19 & 22.40 & 22.92 & 22.62 & 23.17 \\
\hline & 600 & 17.77 & 19.16 & 19.50 & 19.25 & 19.69 & 22.09 & 22.46 & 22.80 & 22.56 & 22.98 \\
\hline \multicolumn{2}{|c|}{ L.S.D at $5 \%$} & \multicolumn{5}{|c|}{1.01} & \\
\hline
\end{tabular}

\section{Water relation :}

\subsection{Water uptake $(\mathrm{ml} /$ flower) :}

The termination of vase life of many cut-flowers is characterized by wilting even though they are constantly held in water. Many studies, therefore, aimed to evaluate the events leading to this phenomenon. In a gross analysis, the following components of water balance can be distinguished: water uptake and transport, water loss and the capacity of the flower tissue to retain its water (Halevy and Mayak, 1981).

Concerning the water uptake as affected by fertilization, irrigation and holding solutions, the data recorded in Table (2) showed in general that, poinsettia plants treated with any fertilization dose, irrigation 
levels combined with silver nitrate (25 ppm $\left.\mathrm{AgNO}_{3}\right)$ produced flowers having superior effect on water uptake value. However, the highest water uptake values (3.26 and $4.10 \mathrm{ml} / \mathrm{fl}$.) resulted from plants fertilized with $0.9 \mathrm{~g} / \mathrm{plant}$, irrigated with $450 \mathrm{ml} / \mathrm{plant}$ and hold in a silver nitrate solution at $25 \mathrm{ppm}$. This was followed by plants treated with the same mentioned preharvest treatments but combined with citric acid at $10 \mathrm{ppm}$ plus sucrose at $15 \mathrm{~g}$ in both seasons $(2.88$ and $3.87 \mathrm{ml} / \mathrm{fl}$.), respectively. Then those treated with a similar preharvest doses but holding solution contained boric acid at $10 \mathrm{ppm}$ plus sucrose at $15 \mathrm{~g} / \mathrm{L}$ that produced water uptake value of 2.82 and 3.80 $\mathrm{ml} / \mathrm{fl}$. in both seasons, respectively.

Table (2): Effect of the interaction between different fertilization, irrigation levels during plant growth period and holding solution treatments on water uptake ( $\mathrm{ml} / \mathrm{flower}$ ) of poinsettia cut-flowers during 1997/98 and 1998/99 seasons.

\begin{tabular}{|c|c|c|c|c|c|c|c|c|c|c|c|}
\hline \multirow{2}{*}{\multicolumn{2}{|c|}{ Treatments }} & \multicolumn{10}{|c|}{ Water uptake (ml/flower) } \\
\hline & & \multicolumn{5}{|c|}{ First season $1997 / 98$} & \multicolumn{5}{|c|}{ Second season 1998/99 } \\
\hline 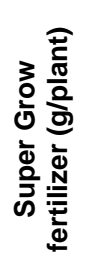 & 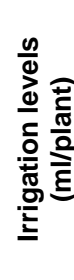 & $\begin{array}{l}\overline{0} \\
\text { 일 } \\
\overline{0}\end{array}$ & 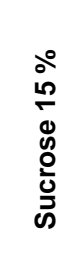 & 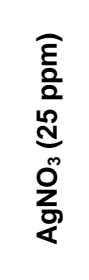 & 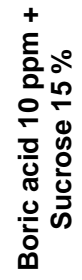 & 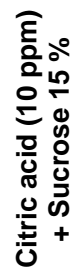 & 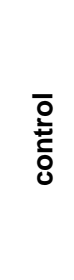 & 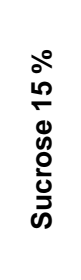 & 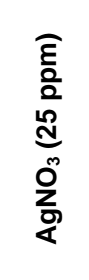 & 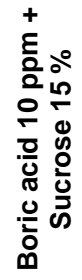 & 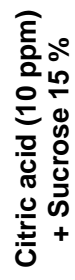 \\
\hline \multirow{4}{*}{ 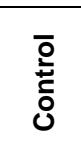 } & 150 & 1.21 & 1.40 & 1.49 & 1.45 & 1.33 & 1.43 & 1.45 & 1.60 & 1.47 & 1.51 \\
\hline & 300 & 1.24 & 1.46 & 1.53 & 1.50 & 1.37 & 1.52 & 1.65 & 1.82 & 1.69 & 1.75 \\
\hline & 450 & 1.29 & 1.50 & 1.59 & 1.53 & 1.43 & 1.57 & 1.74 & 1.93 & 1.87 & 1.79 \\
\hline & 600 & 1.25 & 1.48 & 1.55 & 1.50 & 1.39 & 1.53 & 1.70 & 1.88 & 1.82 & 1.68 \\
\hline \multirow{4}{*}{ o } & 150 & 1.34 & 1.46 & 1.53 & 1.49 & 1.40 & 2.14 & 2.16 & 2.32 & 2.28 & 2.23 \\
\hline & 300 & 1.39 & 1.51 & 1.60 & 1.52 & 1.47 & 2.23 & 2.36 & 2.53 & 2.40 & 2.38 \\
\hline & 450 & 1.44 & 1.53 & 1.63 & 1.58 & 1.50 & 2.28 & 2.45 & 2.64 & 2.58 & 2.41 \\
\hline & 600 & 1.90 & 1.50 & 1.61 & 1.55 & 1.48 & 2.24 & 2.40 & 2.59 & 2.53 & 2.09 \\
\hline \multirow{4}{*}{0} & 150 & 2.30 & 2.48 & 2.57 & 2.50 & 2.46 & 3.25 & 3.27 & 3.42 & 3.30 & 3.32 \\
\hline & 300 & 2.35 & 2.51 & 2.66 & 2.61 & 2.53 & 3.29 & 3.31 & 3.58 & 3.42 & 3.36 \\
\hline & 450 & 2.50 & 2.56 & 2.79 & 2.72 & 2.56 & 3.31 & 3.37 & 3.73 & 3.49 & 3.47 \\
\hline & 600 & 2.46 & 2.49 & 2.70 & 2.64 & 2.54 & 3.29 & 3.48 & 3.67 & 3.55 & 3.40 \\
\hline \multirow{4}{*}{$\stackrel{9}{0}$} & 150 & 2.47 & 2.69 & 3.00 & 2.70 & 2.79 & 3.04 & 3.18 & 3.30 & 3.20 & 3.24 \\
\hline & 300 & 2.51 & 2.72 & 3.17 & 2.78 & 2.83 & 3.47 & 3.48 & 3.90 & 3.60 & 3.61 \\
\hline & 450 & 2.59 & 2.78 & 3.26 & 2.82 & 2.88 & 3.52 & 3.74 & 4.10 & 3.80 & 3.87 \\
\hline & 600 & 2.52 & 2.81 & 3.00 & 2.75 & 2.80 & 3.50 & 3.62 & 3.80 & 3.70 & 3.74 \\
\hline \multicolumn{2}{|c|}{ L.S.D at $5 \%$} & & & 0.87 & & & & & 0.99 & & \\
\hline
\end{tabular}

Finally, the least water uptake values (1.21 and $1.43 \mathrm{ml} / \mathrm{fl}$.) resulted from nonfertilized plants, irrigated with $150 \mathrm{ml} /$ plant and held in water only in both seasons, respectively. These results were in agreement with those obtained by Paul (1976) who found that poinsettias are fairly sensitive to low nutrient 
Hussein, H. A. A. et al.

supply, particularly nitrogen and certain micro-elements and are relatively tolerant to high or even excessive levels of fertility. In addition, it has further been demonstrated that poinsettias thrive under conditions of high fertility and high moisture supply. Marousky (1969 and 1972) mentioned that adding carbohydrates source such as sucrose to the holding solution resulted in an extension of vase life if growth of micro-organisms was controlled, and the increased flower longevity in the acidic solutions was due to the inhibition of vascular blockage and increasing water absorption.

\subsection{Water balance ( $\mathrm{ml} / \mathrm{flower} /$ day) :}

Flower turgidity is the result of the balance between the rate of water uptake and water loss and gains in fresh weight can occur only when the rate of water uptake is greater than the transpiration. Water balance, a central consideration in the longevity of cut-flowers, depends on the relationship between solution uptake and transpiration. Solution uptake depends on transpiration, temperature, $\mathrm{pH}$, microbial pollution and on the whole.

Water balance illustrations from Figs. (1-4) were calculated as the average values of the two seasons. Fig. (1) clarifies the effect on plants fertilized with $0.9 \mathrm{~g} /$ plant, irrigated with four levels and their flowers were held in water only. It was obvious that after 4 days the highest peak of the positive water balance resulted from plants irrigated with $450 \mathrm{ml} /$ plant followed by 300 $\mathrm{ml} / \mathrm{plant}$, then $600 \mathrm{ml} / \mathrm{plant}$ and at the last $150 \mathrm{ml} / \mathrm{plant}$. It should be noticed that water balance reduction began after 6.8 days in flowers of plants irrigated with $450 \mathrm{ml} / \mathrm{plant}$ while in the other irrigation treatments began earlier specially those irrigated with $600 \mathrm{ml} /$ plant (4.84 days). Concerning vase life, there were non-significant differences, however, the longest vase life was of flowers of irrigated plants with $450 \mathrm{ml} /$ plant. Generally, it may be reported that the irrigation doses had an effect on water balance. It is a matter of importance to demonstrate that, the higher water balance induced turgidity and better flower quality through vase life.

When comparing Fig. (2) with Fig. (3) it is evident that, the level of fertilizer during the growing period has a remarkable response on vase life. Since, plants fertilized with $0.9 \mathrm{~g} /$ plant as compared with those fertilized with $0.6 \mathrm{~g} /$ plant only had a longer vase life of 20.25 and 18.0 day respectively. The prementioned results were when the plants and flowers were under the same conditions i.e. (irrigation with $450 \mathrm{ml} /$ plant and held in $\mathrm{AgNO}_{3}$ ). Moreover, the water balance began to decrease from 9-11 days compared with 8.3-10.0 days in this concern, respectively.

Regarding the holding solutions, a variable effect was observed. For example when Fig. (2) was compared with Fig. (4) (when the plants were fertilized with $0.9 \mathrm{~g} / \mathrm{plant}$ and irrigated with $450 \mathrm{ml} / \mathrm{plant}$ ) there were differences in vase life evident when using $\mathrm{AgNO}_{3}(25 \mathrm{ppm}$ ) or holding in sucrose ( 20.25 and 17.0 days, respectively). In addition, water balance began to decrease with sucrose earlier after 5.2 days than those treated with $\mathrm{AgNO}_{3}$ after 11.0 days.

Generally, it could be added that sucrose plays an important role in improving the water balance of inflorescences by affecting the osmotic potential and the water holding capacity of the tissue allowing less water to 
be transpired. The only disadvantage of sucrose is that micro-organisms growth would increase in pollution, thus, the citric acid was the most widely added agent to decrease the $\mathrm{pH}$ of water, improve water balance and reduce stem plugging. As a consequence, the combination of both citric acid and sucrose would result in water balance. Citric acid also, showed a positive effect on increasing the longevity, especially when combined with other chemicals such as sucrose (Halevy et al., 1978).

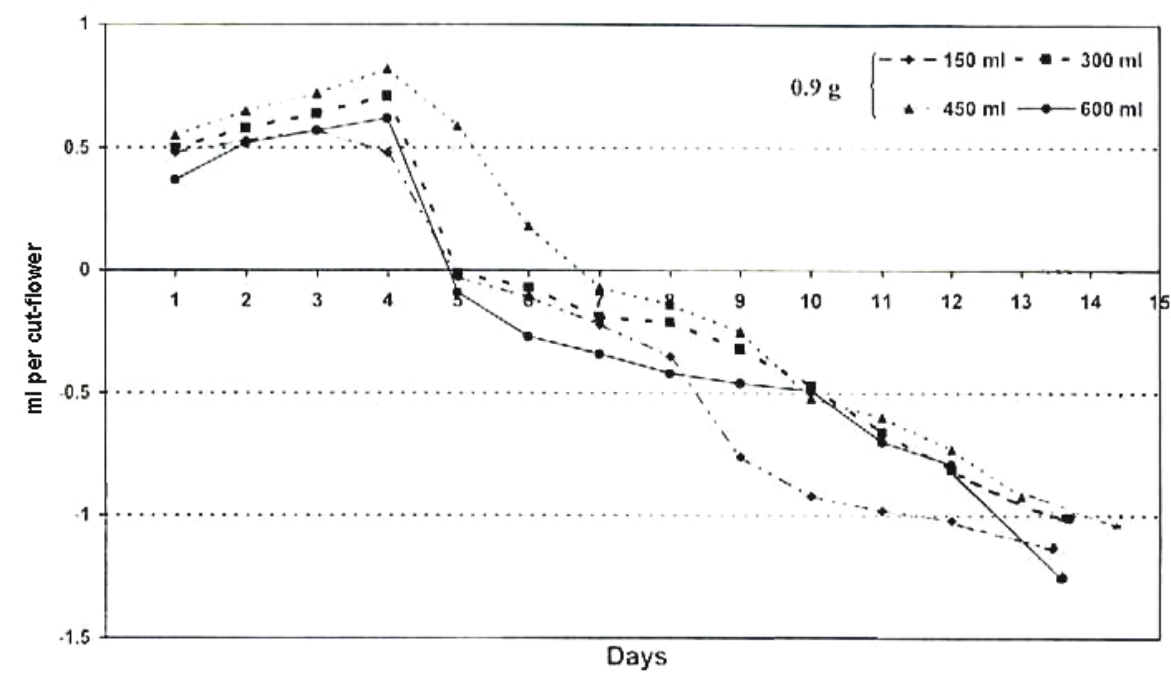

Fig. (1) : Water balance (ml/flower/day) of poinsettia cut-flowers treated with $0.9 \mathrm{~g} / \mathrm{plant}$ Super Grow at different irrigation levels affected by holding in a distilled water (means of the two seasons).

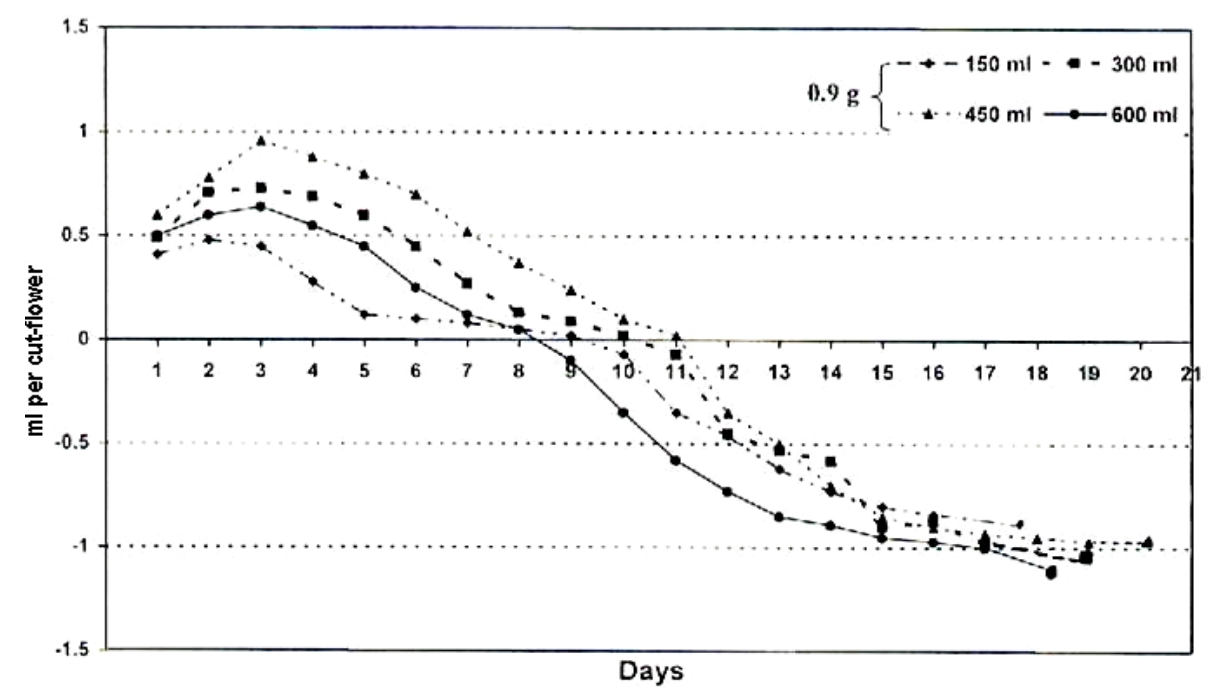

Fig. (2) : Water balance (ml/flower/day) of poinsettia cut-flowers treated with $0.9 \mathrm{~g} / \mathrm{plant}$ Super Grow at different irrigation levels affected by holding in AgNO3 at $25 \mathrm{ppm}$ solution (means of the two seasons). 
Hussein, H. A. A. et al.

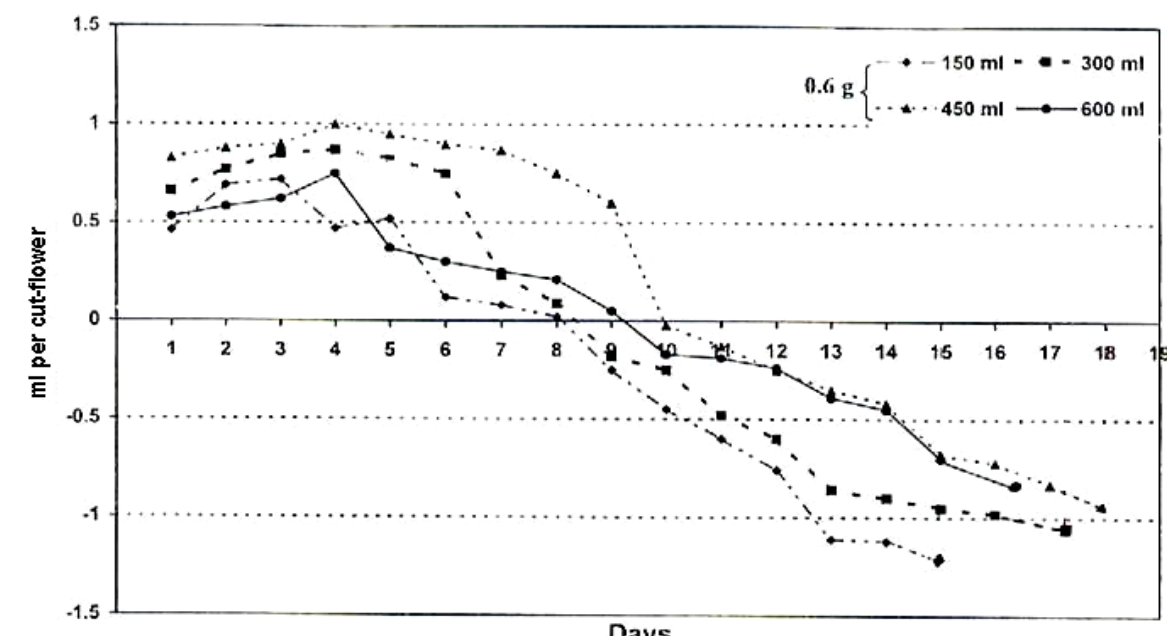

Fig. (3) : Water balance ( $\mathrm{ml} /$ flower/day) of poinsettia cut-flowers treated with $0.6 \mathrm{~g} / \mathrm{plant}$ Super Grow at different irrigation levels affected by holding in AgNO3 at $25 \mathrm{ppm}$ solution (means of the two seasons).

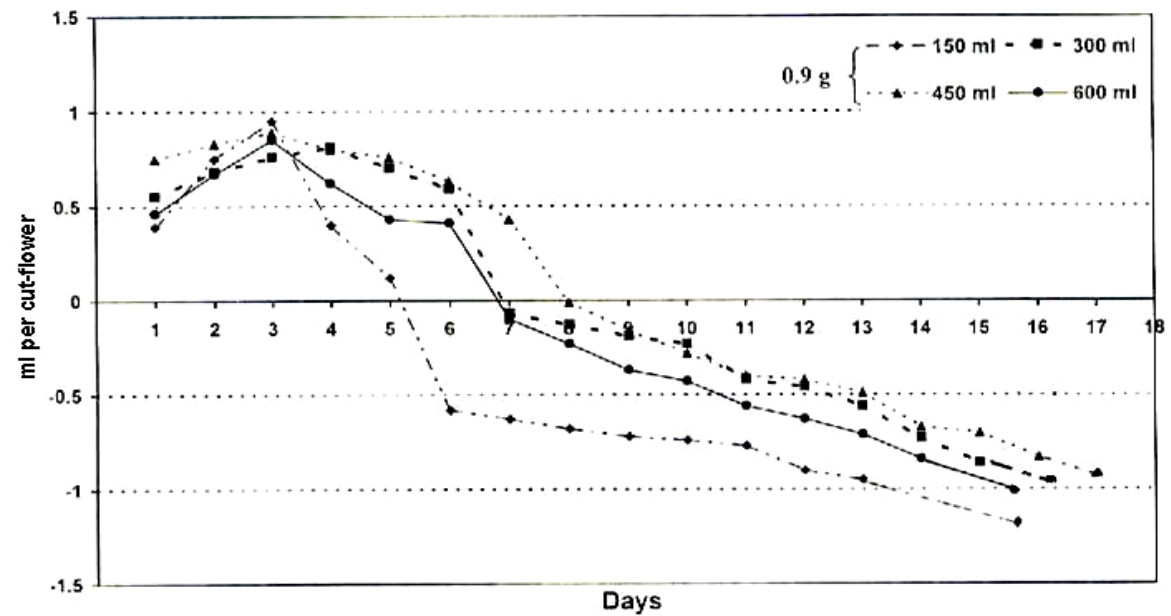

Fig. (4) : Water balance ( $\mathrm{ml} /$ flower/day) of poinsettia cut-flowers treated with $0.9 \mathrm{~g} / \mathrm{plant}$ Super Grow at different irrigation levels affected by holding in sucrose (15\%) solution (means of the two seasons).

\section{Vase life :}

There are several fundamental causes for the deterioration and death of fresh cut flowers, any thing that florists do to prolong their vase life will be related one or more of these factors. Post and Fischer (1952) mentioned that the basic causes for the deterioration of flowers are : 1) The exhaustion of respirable substrates, 2) Desiccation or drying out, 3) Maturation and continued development of the flowers, 4) Ravages of diseases, 5) Ethylene injury, 6) Fading of flower colour or colour changes. 
Reviewing the data in Table (3) in general it may be observed obviously the greatest effect of preharvest treatments on vase life in the two seasons. Moreover, the effect of holding solutions was quite clear when compared with holding flowers in just water.

In addition, it appeared that the highest level of fertilizer at $0.9 \mathrm{~g} / \mathrm{plant}$ maintained the plant with the suitable requirements leading to prolong vase life. These results were in agreement with the results obtained by Paul (1976) who found that poinsettias are fairly sensitive to low nutrient supply, particularly nitrogen and certain micro-elements and are relatively tolerant to high or even excessive levels of fertility, and supported by the finding of Roy (1980) mentioned that poinsettias require high levels of the major elements particularly nitrogen and soil fertility levels must be carefully controlled. However, the basic requirement of high nitrogen with moderate phosphorus and potassium can be met by complete fertilizers. Moreover, Joanna and Ryszard (1990) in order to produce flowers of acceptable quality, it is necessary to maintain an optimal (but not excessive) fertilization program until harvest stage.

Moreover, the longevity of vase life (19.75 and 20.75 days) was associated with the moderate watering at $450 \mathrm{ml} /$ plant since close attention to watering is critical stress imposed by excessive or inadequate water in the medium during growing period which reduces the quality and the vase life of cut flowers in general leading to acceleration of senescence. In this concern, Mayak and Kofranek (1976) showed that grown carnations under a normal irrigation regime, produced flowers with better vase life than those grown at wet and low irrigation regimes. In addition, Han et al. (1997) found that in the treatments not irrigated for 4 and 8 weeks, the roses yield high-quality cut flowers as was increased by $24-28 \%$ compared with control plants.

Regarding the effect of the holding solutions on vase life of poinsettia cut flowers, the data reported in the same Table, showed that using silver nitrate $(25 \mathrm{ppm})$ produced significantly the longest vase life (19.75 and 20.75 days) other than citric acid plus sucrose, boric acid plus sucrose and sucrose only in both seasons, respectively. Concerning boron it was mentioned in previous researches that it influences the vase life. Its mode of action is associated with control of microbial activity or control metabolism of flowers. Finally, the longest vase life (19.75 and 20.75 days) were produced from plants treated with the fertilizer at $0.9 \mathrm{~g} / \mathrm{plant}$.

These results may be related basically to silver nitrate which is an effective bactericide. Silver nitrate is often supplied in vase solutions for the extension of flower life. Micro-organisms grow in the vase water include bacteria, yeasts and molds which are harmful to cut flowers through their development and their consequent blockage of the xylem. They also produce ethylene and toxins which accelerate flower senescence. It is well known that poinsettia is sensitive to ethylene.

In addition, carbohydrates are the main source of nutrition for flowers as well as the source of energy necessary for maintaining all biochemical and physiological processes after separation from the mother plant. Sugars support processes fundamental for prolonging vase life such as maintaining 
Hussein, H. A. A. et al.

mitochondrial structure and functions, improving water balance by regulating transpiration and increasing water uptake.

Table (3) : Effect of the interaction between different fertilization, irrigation levels during plant growth period and holding solution treatments on vase life (days) of poinsettia cut flowers during 1997/98 and 1998/99 seasons.

\begin{tabular}{|c|c|c|c|c|c|c|c|c|c|c|c|}
\hline \multirow{2}{*}{\multicolumn{2}{|c|}{ Treatments }} & \multicolumn{10}{|c|}{ Vase life (days) } \\
\hline & & \multicolumn{5}{|c|}{ First season 1997/98 } & \multicolumn{5}{|c|}{ Second season 1998/99 } \\
\hline 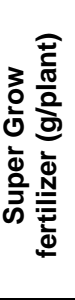 & 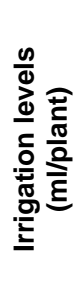 & 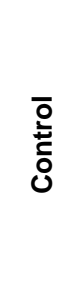 & 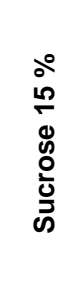 & 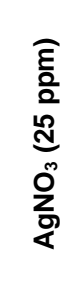 & 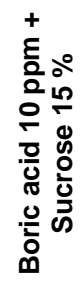 & 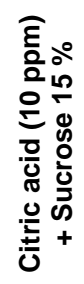 & 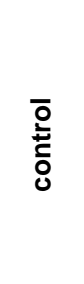 & 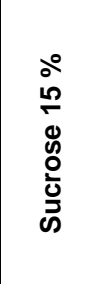 & 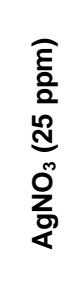 & 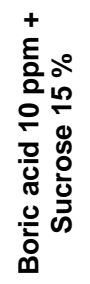 & 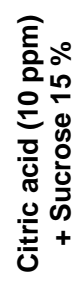 \\
\hline \multirow{4}{*}{$\begin{array}{l}\overline{0} \\
\text { 는 } \\
\text { d }\end{array}$} & 150 & 6.25 & 10.00 & 12.00 & 10.25 & 11.25 & 7.50 & 11.00 & 13.25 & 11.50 & 12.50 \\
\hline & 300 & 6.75 & 10.25 & 12.75 & 10.75 & 11.75 & 8.00 & 11.75 & 13.25 & 12.50 & 13.00 \\
\hline & 450 & 7.25 & 10.75 & 13.25 & 11.00 & 12.25 & 9.00 & 12.50 & 14.25 & 13.25 & 13.50 \\
\hline & 600 & 7.50 & 10.00 & 12.50 & 10.75 & 11.50 & 8.75 & 11.25 & 12.75 & 12.00 & 12.75 \\
\hline \multirow{4}{*}{$\stackrel{m}{0}$} & 150 & 9.00 & 12.50 & 13.25 & 13.00 & 10.75 & 11.00 & 11.50 & 14.25 & 11.75 & 13.00 \\
\hline & 300 & 9.25 & 13.00 & 14.50 & 13.75 & 12.00 & 12.75 & 12.00 & 15.25 & 12.50 & 13.50 \\
\hline & 450 & 9.75 & 13.25 & 15.00 & 14.25 & 13.25 & 13.00 & 12.75 & 16.25 & 13.00 & 14.25 \\
\hline & 600 & 9.00 & 12.50 & 13.50 & 13.25 & 11.50 & 11.50 & 12.25 & 14.00 & 12.25 & 13.25 \\
\hline \multirow{4}{*}{$\stackrel{0}{\circ}$} & 150 & 12.25 & 13.25 & 14.25 & 13.50 & 13.75 & 13.00 & 15.00 & 15.75 & 14.25 & 15.00 \\
\hline & 300 & 12.75 & 14.75 & 16.50 & 15.25 & 14.25 & 13.50 & 16.00 & 18.00 & 17.25 & 17.00 \\
\hline & 450 & 13.25 & 15.25 & 17.25 & 16.00 & 16.75 & 14.00 & 16.75 & 18.75 & 17.75 & 18.25 \\
\hline & 600 & 12.50 & 13.00 & 15.50 & 13.75 & 14.00 & 13.25 & 15.25 & 17.25 & 15.75 & 16.25 \\
\hline \multirow{4}{*}{ gृ } & 150 & 13.00 & 15.00 & 17.75 & 15.75 & 16.25 & 13.75 & 16.00 & 18.00 & 16.00 & 17.25 \\
\hline & 300 & 13.50 & 16.25 & 18.50 & 16.50 & 17.25 & 14.25 & \begin{tabular}{|l|}
16.50 \\
\end{tabular} & 19.50 & 16.75 & 17.75 \\
\hline & 450 & 13.75 & 17.00 & 19.75 & 17.50 & 18.50 & 14.75 & 17.00 & 20.75 & 17.75 & 18.00 \\
\hline & 600 & 13.25 & 15.75 & 18.00 & 16.00 & 16.75 & 14.00 & 15.75 & 18.75 & 16.25 & 17.00 \\
\hline \multicolumn{2}{|c|}{ L.S.D at $5 \%$} & \multicolumn{5}{|c|}{1.01} & \multicolumn{5}{|c|}{1.11} \\
\hline
\end{tabular}

\section{REFERENCES}

Freyermuth, T.; E.J. Holcomb and K. Evensen (1984). Post-harvest notes cut poinsettia. Pennsylvania Flower Growers, Bulletin 353, Third Issue.

Gomez, K.A. and A.A. Gomez (1984). Statistical Procedures for Agricultural Research. John Wiley and Sons, Inc., New York.

Gordon, J.; K. Evensen and E.J. Holcomb (1986). Alcohol pre-treatment of cut poinsettia. Hort. Sci. October, Vol. 21: P.5.

Halevy, A.H.; A.M. Kofranek and S.T. Besemer (1978). Post-harvest handling methods for bird of paradise flowers (Strelitzia reginae Ait). J. Amer. Soc. Hort. Sci., 103: 165-169.

Halevy, A.H. and S. Mayak (1981). Senescence and post-harvest physiology of cut flowers. Part II. Hort. Rev., 3: 59-143.

Han, Y.Y.; J. Woo; Y.K. Sim and B. Chol (1997). Effect of non-irrigation pruning methods during summer dormancy on yield and quality of cut-rose. J. Karnean Society for Hort. Sci., 38(5): 527-532. 
James, B.S. (1980). Introduction to Floriculture. Current status. North Carolina State Univ. 1 SBN, 0-12-437650-9: 303-304.

Joanna, N. and M. Ryszard (1990). Post-harvest, Handling and Storage of Cut Flowers, Florist Greens and Potted Plants. Chapman and Hall, London P. 32.

Marousky, F.J. (1969). Conditioning gladiolus spikes to main-tenance of fresh weight with pre-treatments of 8-hydroxy-quinoline citrate plus sucrose. Proc. Fla. State Hort. Soc., 82: 411-414.

(1972). Water relations, effects of floral preservatives on bud opening and keeping quality of cut-flowers. Hort. Sci., 7: 114-116.

Mayak, S. and A. Kofranek (1976). Altering the sensitivity of carnation flowers (Dianthus caryophyluss, L.) to ethylene. J. Amer. Soc. Hort. Sci., 101: 503-506.

Nell, T.A.; R.T. Leonard; J.E. Barrett; T. Fjeld and E. Stromme (1995). Production factors affect the post-production performance of poinsettia, a review. Sixth International Symposium on Postharvest Physiology of Ornamental Plants, Oslo, Norway, 17-22 June. Acta Hort., 405: 132-137.

Paul, E.J.R. (1976). Paul Ecke Poinsettias, The Poinsettia Encinitas Manual, Inc. Santa California, USA. P.11.

Post, K. and C.W. Fischer (1952). Commercial storage of cut flowers, N.Y. (Cornell). Agr. Ext., 853, P. 1-14.

Roy, A.L. (1980). Introduction to Floriculture. Academic Press, Inc. P: 301326.

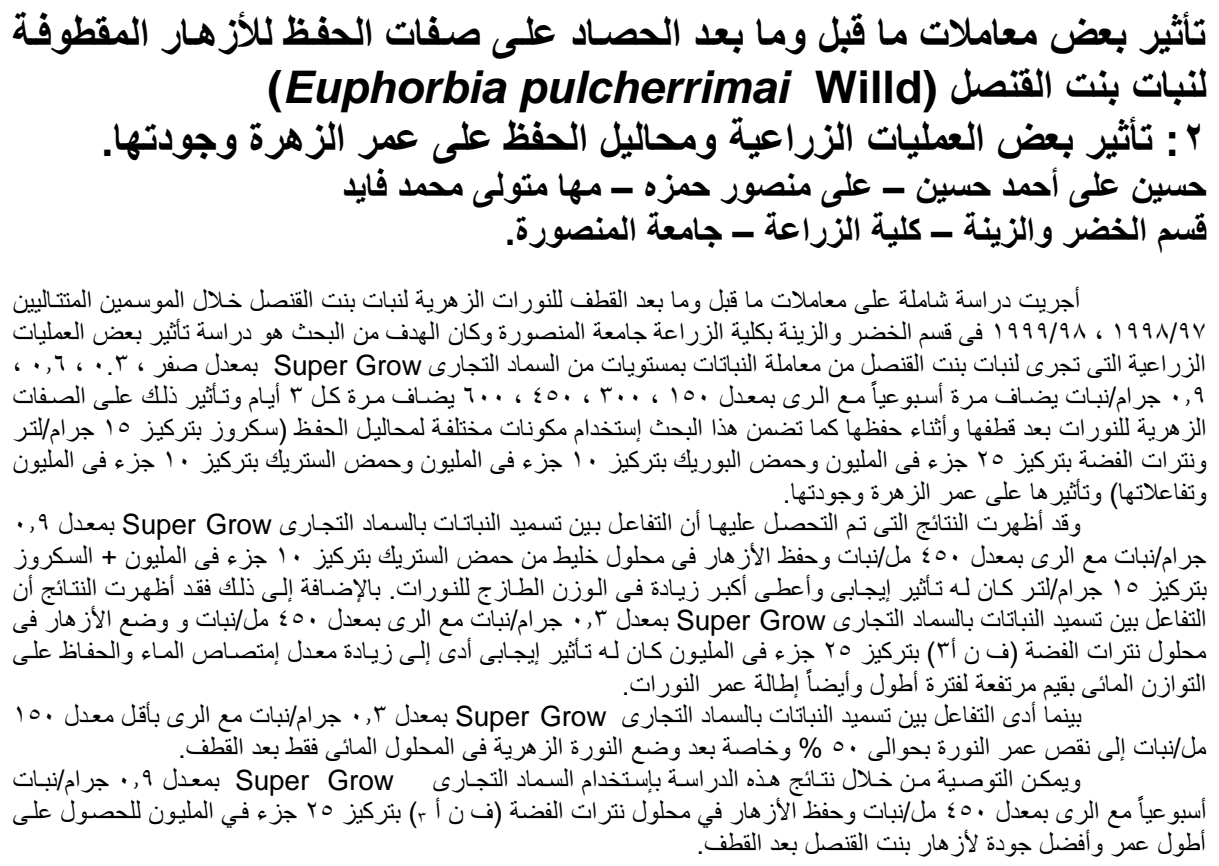


Hussein, H. A. A. et al.

2796279727982799280028012802280328042805

2796279727982799280028012802280328042805 